\title{
BIOCONTROL POTENTIAL OF SOME ENTOMOPATHOGENIC NEMATODES AGAINST STELIDOTA GEMINATA (SAY)
}

\author{
${ }^{a}$ Institute for Phytomedicine, University of Belgrade-Faculty of Agriculture, Nemanjina 6, 11080 Beograd-Zemun, \\ Serbia; \\ ${ }^{b}$ Faculty of Agriculture, University of Banja Luka, Bulevar vojvode Petra Bojovica 1A, 78000 Banja Luka, Bosnia and \\ Herzegovina; \\ ${ }^{c}$ Department of Agricultural and Environmental Science, University of Bari Aldo Moro, via Giovanni Amendola \\ 165/A, 70126 Bari, Italy; \\ ${ }^{d}$ Department of Soil, Plant and Food Sciences, University of Bari Aldo Moro, via Giovanni Amendola 165/A, 70126 \\ Bari, Italy; \\ Corresponding Author: Eustachio Tarasco; eustachio.tarasco@uniba.it
}

Grujić N., Nježić B., Anifantis S.A., Tarasco E. - Biocontrol potential of entomopathogenic nematodes against Stelidota geminata (Say)

Stelidota geminata (Say) (Coleoptera: Nitidulidae), also known as strawberry sap beetle is considered to be serious pest of strawberry worldwide. All stages of this pest feed on ripe fruitswhich makes its control with chemical insecticides extremely difficult. This work was testing susceptibility of last instar larvae of $S$. geminata to three, among commercially the most commonly used species of entomopathogenic nematodes Heterorhabditis bacteriophora, Steinernema carpocapsae and Steinernema feltiae (Rhabditida: Heterorhabditidae and Steinernematidae), including two native strains. The present work was carried out through two types of the experiments. First experiment was in plastic Petri dishes with the nematodes applied on filter paper. Second one, in attempt to approach to more natural conditions, effect of the entomopathogenic nematodes on insect's mortality was tested in containers filled with sand. Mortality of S. geminata larvae in Petri dishes in highest nematode concentrations of about 100 infective juveniles per $\mathrm{cm}^{2}$ was $90 \%$, $82 \%$ and $70 \%$ for commercial strains of S. carpocapsae, H. bacteriophora and S. feltiae and $76 \%$ and $64 \%$ for $H$. bacteriophora and S. feltiae native populations. In containers with sand mortality was higher than in Petri dishes and the highest recorded insect mortality with about 50 nematodes per $\mathrm{cm}^{2}$ was $99.5 \%, 89 \%, 75.5 \%, 69 \%$ and $66 \%$ with commercial strains $S$. feltiae, $S$. carpocapsae and H. bacteriophora, and native strains $H$. bacteriophora and $S$. feltiae, respectively.

KEY WoRDS: Strawberry sap beetle, Entomopathogenic nematodes, Biological control.

\section{INTRODUCTION}

Strawberry sap beetle, Stelidota geminata (Say) (Coleoptera: Nitidulidae) is an insect pest of strawberry, peach, and some other plants. It has been introduced in Europe in the past decades and recently has been recorded in Serbia (SPASIĆ, 2011). Several years later it was recorded as a pest in Bosnia and Herzegovina (NJEŽı́, personal observation). In both countries strawberries were mostly affected. This pest feeds on ripen strawberry fruits, which put the use of chemical insecticides impossible. It overwinters as an adult stage with unknown place of overwintering, which makes preventive control difficult. When fruits start ripening imago migrates into strawberry fields and starts feeding and females lay eggs in damaged fruits. Hatched larvae also feed there and third last larval instar of $S$. geminata after one day of wandering on the soil surface migrates into the soil. There it makes a pupal cell 1.5 $\mathrm{cm}$ below the surface (WEBERAND and CONNELL, 1975), which makes those, developmental soil dwelling

- Received 20 March 2020 Accepted 18 June 2020 stages, an easy target for soil born agents.

Entomopathogenic nematodes (EPN) are the most promising biocontrol agents among nematodes. Although the first species of EPN has been described almost 100 years ago, their inundative application only started about 30 years ago. Increased understanding of the nematode biology, host range, epizootiology, advances in production technology, formulation, storage and application resulted in an exponential increase of interest in the market (ARTHURS et al., 2004). Beside research advances, their rapid expansion was supported also by exemption or ease of registration based on reports of no effect on humans, mammals and plants or environment (EHLERS, 2005). Their successful biocontrol attributes are based on the unique partnership of host seeking nematodes and lethal insectpathogenic bacterium carried inside the nematode's intestine (POINAR, 1993). Half a century had to pass from description of the first species to their mass production due to the development of cheap broad-spectrum insecticides that shifted attention away from biocontrol agents. Since 
the 1980s, application of EPN has experienced growth due to the development of relatively cheap, large scale liquid culture production technology and pressure on pesticide use due to the development of resistance, surpassing residue levels in food and negative impacts on the environment.

Good efficacy of EPN was demonstrated against numerous soil dwelling pests from various insect families (RIGA et al., 2006; TOEPFER et al., 2008; SUSURLUK, 2008; SHAPIRO-ILAN et al., 2010; WILLIAMS et al., 2013) including Nitidulidae and some species of sap beetles (GLAZER et al., 1999; NIELSEN and PHILIPSEN, 2005; GLAZER et al., 2007).

The aim of the present work was to study the susceptibility of $S$. geminata to three commercially frequently used species of EPN including two native strains. To our knowledge, there is no literature data on this subject.

\section{MATERIALS AND METHODS}

Stelidota geminata was reared on bananas in plastic containers with $3 \mathrm{~cm}$ of moist sand on the bottom. About 3-4 mm long last larval instars were taken for the experiment. Three species of EPN were used in the experiments: Heterorhabditis bacteriophora Poinar, Steinernema carpocapsae (Weiser) and Steinernema feltiae Filipjev (Rhabditida: Heterorhabditidae and Steinernematidae). Commercial strains $\quad$ Nematop $^{\circledR}, \quad$ Nemastar $^{\circledR}$ and Nemaplus ${ }^{\circledR}$ from E-nema $\mathrm{GmbH}$ ) of all mentioned EPN were used in experiments in the first year. In the second year, two more local populations of $H$. bacteriophora and $S$. feltiae isolated from soil samples from localities Prnjavor and Banja Luka respectively in Bosnia and Herzegovina, were added. EPN populations were maintained on last instars of Mediterranean flour moth, Ephestia kuhniella (Zeller) (Lepidoptera, Pyralidae) larvae (in the first-year experiments) and greater wax moth, Galleria mellonella L. (Lepidoptera, Pyralidae) (in the second-year experiments). Extracted infective juveniles (IJ) were stored at $4{ }^{\circ} \mathrm{C}$. IJ not older than 15 days were used in the experiments.

Two types of experiments were carried out. Firstly, bioassay was carried out in small plastic Petri dishes $(35 \mathrm{~mm}$ in diameter) with filter paper covering the bottom surface. Four nematode concentrations were used: 50, 200, 500 and 1000 IJ per Petri dish (or around 5, 20, 50 and 100 IJ per $\mathrm{cm}^{2}$ ), each in 10 repeats with five $S$. geminata larvae per Petri dish. Volume of $0.5 \mathrm{ml}$ of suspension with nematodes in given concentrations has been transferred by pipetting on filter paper. Subsequently, larvae were transferred to Petri dishes and then sealed with parafilm. The results were checked after seven days and mortality recorded. Each dead larva was dissected using a dissection microscope and examined for the presence of EPNs.
The second experiment was carried out in $200 \mathrm{ml}, 9 \mathrm{~cm}$ in diameter plastic containers filled with $150 \mathrm{~g}$ of sand with $13 \%$ moisture (previously sterilized at $200^{\circ} \mathrm{C}$ for two hours). Two concentrations of EPN were used, $1500 \mathrm{IJ}$ and 3000 IJ per container (or about 25 and 50 nematodes per $\mathrm{cm}^{2}$ of the sand surface, respectively). Approximately one hour after transferring nematodes 20 last instar larvae were added per repeat and containers were loosely sealed. Experiment was carried in 10 repeats in each concentration including negative control without nematodes. After15 days sand was gently rinsed with water over the $1 \mathrm{~mm}$ sieve to check for ecloded imago. In the second year, experiment with a commercial strain of $H$. bacteriophora $\left(\right.$ Nematop $\left.^{\circledR}\right)$ was repeated. All experiments were conducted in the laboratory at room temperature $\left(20-23^{\circ} \mathrm{C}\right)$.

Analysis of variance (ANOVA) was performed on the data using SAS 9.4 software (SAS Institute Inc.). To evaluate the differences between separate means the LSD test was used. All comparisons were made at 0.05 level of significance.

\section{RESULTS}

\section{EXPERIMENT I}

Our results show that $S$. geminata is highly susceptible to all three species examined. Mortality rates of S. geminata larvae recorded (Fig. I) increased with increasing gradient of nematode concentration per Petri dish ranging from 14 to $90 \%$. The highest mortality was recorded with highest concentration of IJ and was $90 \%$; $82 \%$ and $70 \%$ for commercial strains of $S$. carpocapsae, H. bacteriophoraand $S$. feltiae respectively. Susceptibility of $S$. geminata to native strains was lower than to commercial EPN populations but usually not statistically different (Fig. I). Mortality rate in control was $10 \%$. All stages of nematodes were recorded in dead insects including the new generation of IJ. The number of observed nematodes ranged from just a couple of adults and/or juveniles to more than hundred nematodes per larva (data not presented).

\section{EXPERIMENT II}

Results of experiment II confirmed previous results. $S$. geminata larvae were susceptibile to all three EPN species in sand. Both strains of $H$. bacteriophora showed lowest virulence at lowest concentration of IJ and at the highest was similar to native strains of about $70 \%$. The best results, with mortality of $S$. geminata of almost $100 \%$ were obtained with 3000 IJ of $S$. feltiae (Nemaplus) while lower IJ concentration caused larval mortality of $92.5 \%$, similar to the highest IJ concentration of $S$. carpocapsae $\left(\right.$ Nemastar $\left.^{\circledR}\right)$ (Fig. II). 


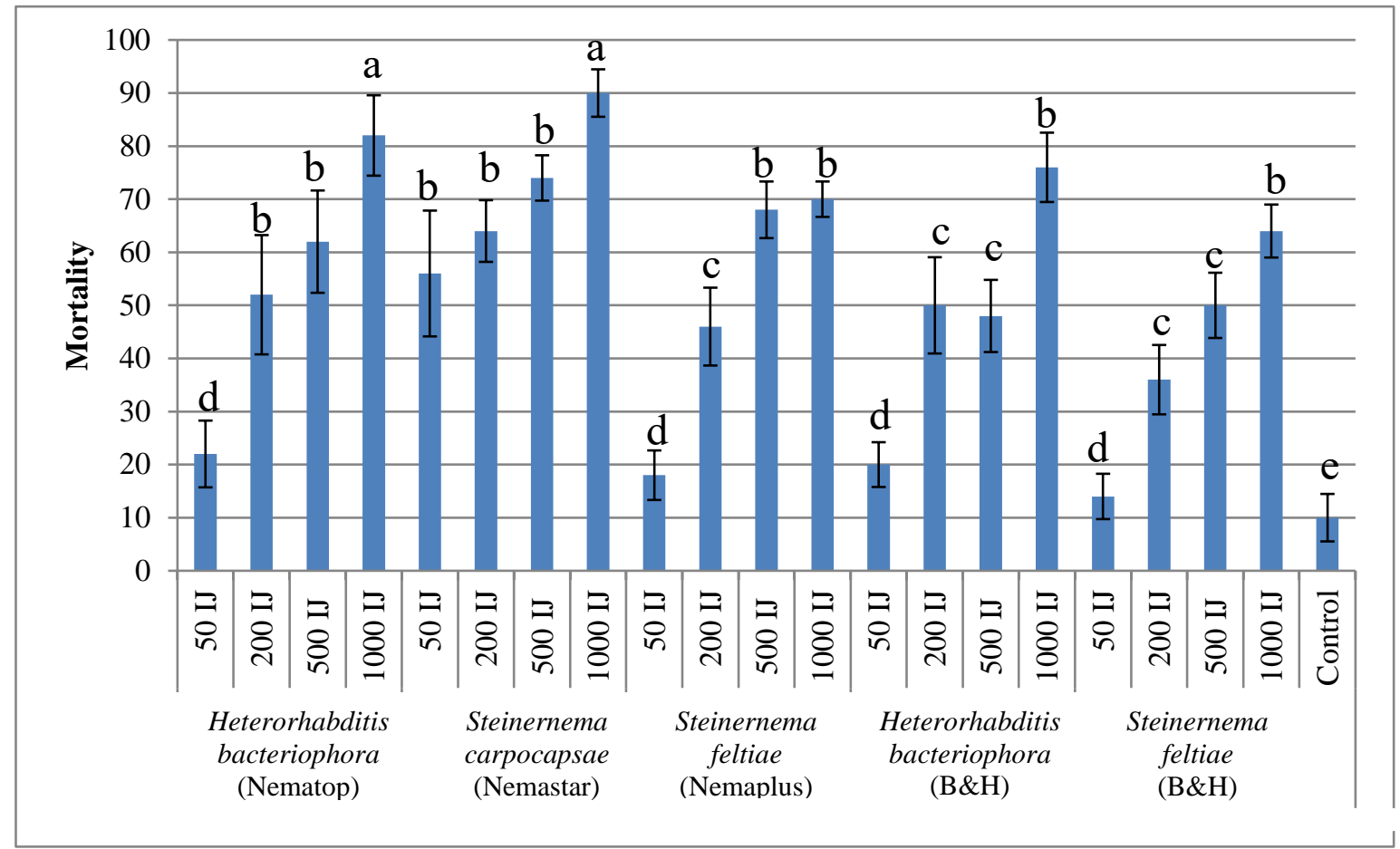

Fig. I - Mortality of Stelidota geminata larvae caused by 50, 200, 500 and 1000 infective juveniles of entomopathogenic nematodes per repeat in Experiment I in Petri dishes. Bars with the same letter are not significantly different $(\mathrm{P}<0.05)$.

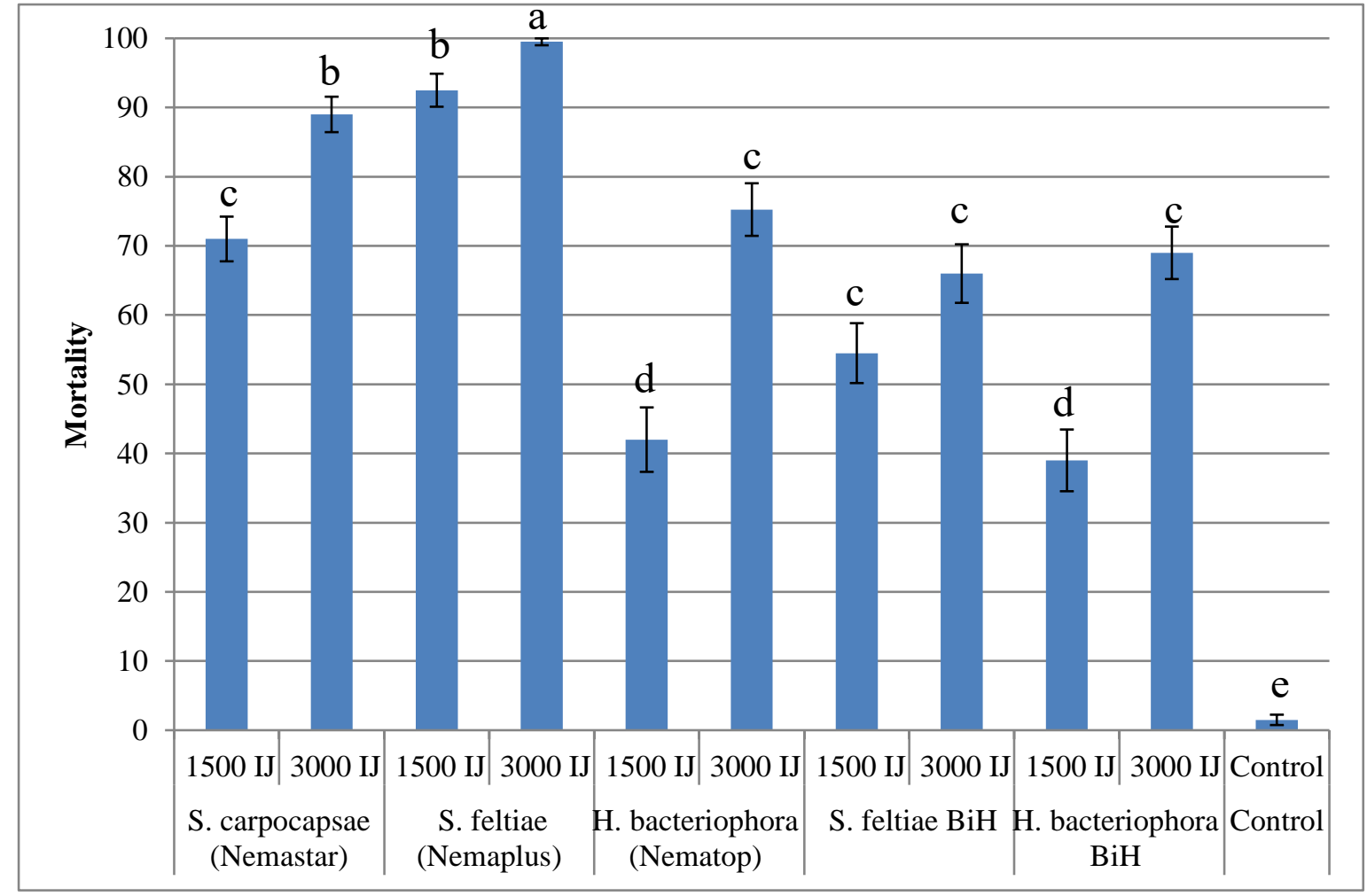

Fig. II - Mortality of Stelidota geminata larvae caused by 1500 and 3000 infective juveniles of entomopathogenic nematodes per repeat in experiment II in containers with sand. Bars with the same letter are not significantly different $(\mathrm{P}<0.05)$. 


\section{DISCUSSIONS AND CONCLUSIONS}

The results of this work show the susceptibility of strawberry sap beetle to all three species of EPN tested which have not been recorded previously. Highest mortality caused by $S$. carpocapsae in experiment I was expected considering it is ambusher strategy (CAMPBELL and GAUGLER, 1997) of host finding, the design of the experiment and the highly motile larvae. However, it might be expected that other EPN strains would cause higher mortality at the highest IJ concentration. It may be explained by the inability of cruisers strategists to move appropriately in artificial environment such as filter paper (WILLIAMS et al., 2013). Nitidulid larvae and pupae showed moderate to high susceptibility to EPN (GLAZER et al., 1999; GLAZER et al., 2007; ElLIS et al., 2010) and this study confirmed it.

In more natural environment, in the second experiment, S. feltiae $\left(\right.$ Nemaplus $\left.^{\circledR}\right)$ with intermediate foraging strategy (GREWAL et al., 1994), caused the highest insects' mortality in both IJ concentration. GLAZER et al. (1999) showed similar differences in experiments on filter paper and sand, in mortality of other sap beetles. Lower than expected insect larvae mortality caused by $H$. bacteriophora $\left(\right.$ Nematop ${ }^{\circledR}$ ) may be caused by loss of virulence of bacterial symbionts due to prolonged strain stay in refrigerator (ANDALO et al., 2011).

Our results suggest that all three EPN species tested might be potential biological control agents in S. geminata management. The highest recorded mortality of S. geminata of $99.5 \%$ obtained with 3000 IJ of S. feltiae (Nemaplus ${ }^{\circledR}$ ) is promising complete control of formation of the second generation of this pest of strawberry. Since sap beetles spend portion of its life cycle in the soil, they present potentially good target to EPN. Providing optimal conditions for EPN in field trials, these nematodes could have high level of control of this pest. Introduction of an alternative biocontrol agent may be of greater significance in countries where strawberry sap beetle is emerging as invasive pest of this important culture, where as allochtone species is probably lacking natural enemies. Important aspect observed during the study is a reproduction of EPN in infected insects that provided progeny that could prolong strawberry protection due to increased persistence of virulent IJ in soil. Further experiments of testing effect of EPN in the natural environment are planned and needed.

\section{ACKNOWLEDGEMENTS}

The authors wish to acknowledge Ralf-Udo Ehlers and E-nema GmbH who kindly provided EPNs' commercial strains.

\section{REFERENCES}

Andalo V., Moino A. JR., Maximiniamo C., CAmpos V.P., MENDONCA L.A., 2011 - Influence of temperature and duration of storage on the lipid reserves of entomopathogenic nematodes. - Revista Colombiana de Entomologia, 37(2): 203-209.

ARTHURS S., HEINZ K.M., PRASIFKA J.R., 2004 - An analysis of using entomopathogenic nematodes against above-ground pests. - Bulletin of Entomological Research, 94: 297-306.

CAMPBELL J.F., GAUGLER R., 1997 - Inter-specific variation in entomopathogenic nematode. Foraging strategy: dichotomy or variation along a continuum? - Fundamental and Applied Nematology, 20: 393-398.

EHLERS R.-U., 2005 - Forum on Safety and Regulations. In: Nematodes as Biocontrol Agents, P. S. Grewal, R.U. Ehlers, \& D. I. Shapiro-Ilan (Eds.), Wallington, United Kingdom: CABI Publishing, pp.107-114.

ElLIS J.D.L., SPIEWOK S., DELAPLANE K.S., BuChHOlZ S, NEUMANN P., TEDDERS W.L., 2010 - Susceptibility of Aethina tumida (Coleoptera: Nitidulidae) larvae and pupae to entomopathogenic nematodes. - Journal of Economic Entomology, 103(1):1-9.

Glazer I., SAlame L., Goldenberg S., Blumberg D., 1999 - Susceptibility of Sap Beetles (Coleoptera: Nitidulidae) to Entomopathogenic Nematodes. - Biocontrol Science \& Technology, 9: 259-266

Glazer I., Eliyau M., Salame L., Nakash Y., BlumBERG D., 2007 - Evaluation of the efficacy of the entomopathogenic nematodes Heterorhabditis ssp. against sap beetles (Coleoptera: Nitidulidae). - BioControl, 52: $259-270$

GREWAL P.S., LEWIS E.E., GAUGLER R., CAMPBELL J.F., 1994 - Host finding behavior as a predictor of foraging strategy in entomopathogenic nematodes. - Parasitology, 108: 207215

GREWAL P.S., EHLERS R.-U., SHAPIRO-ILAN D.I., 2005 Nematodes as biocontrol agents. Wallington: CABI Publishing.

LACEY L., GEORGIS R., 2012 - Entomopathogenic nematodes for control of insect pests above and below ground with comments on commercial production. Journal of Nematology, 44(2): 218-225.

NIELSEN O., PHILIPSEN H., 2005 - Susceptibility of Meligethes spp. and Dasyneura brassicae to entomopathogenic nematodes during pupation in soil. - BioControl, 50: 623-634.

PETERS, A. 1996 - The natural host range of Steinernema and Heterorhabditis spp. and their impact on insect populations. - Biocontrol Science and Technology, 6: 389-402.

POINAR G.O. JR., 1993 - Origins and phylogenetic relationships of the entomophilic Rhabditids, Heterorhabditis and Steinernema. - Fundamental and Applied Nematology, 16(4): 333-338 
RIGA E., LACEY L.A., GUERRA N., HEADRIK H.L., 2006 Control of the Oriental Fruit Moth, Grapholita molesta, using entomopathogenic nematodes in laboratory and fruit bin assays. - Journal of Nematology 38: $168-171$.

SAS, 2013 - SAS® 9.4, SAS Institute Inc., Cary, North Carolina, USA.

SHAPIRO-IllAN D.I., MORALES-RAMOS J.A., ROJAS M.G., TEDDERS W.L., 2010 - Effects of a novel entomopathogenic nematode-infected host formulation on cadaver integrity, nematode yield, and suppression of Diaprepes abbreviatus and Aethina tumida. - Journal of Invertebrate Pathology, 103:103-108.

SPASIĆ R., SMILJANIĆ D., ĐORDEVIĆ B., GRAORA D., 2011 - The first finding of Stelidota geminata (Say) (Coleoptera: Nitidulidae) on strawberry fruits in Serbia. Plant doctor, 4: 419-425.

SUSURLUK A., 2008 - Potential of the entomopathogenic nematodes Steinernema feltiae, S. weiseri and Heterorhabditis bacteriophora for the biological control of the sugar beet weevil Bothynoderes punctiventris (Coleoptera: Curculionidae). - Journal of Pest Science, 81: 221-225.
Toepfer S., Peters A., EHLERS R.-U.,KuhlmanN U., 2008 - Comparative assessment of the efficacy of entomopathogenic nematode species at reducing western corn rootworm larvae and root damage in maize. - Journal of Applied Entomology, 132: 337-348

WEBER R.G., CONNELL W.A., 1975 - Stelidota geminata (Say): Studies of Its Biology (Coleoptera: Nitidulidae). - Annals of the Entomological Society of America, 68(4): 649-653.

WILliams C.D., DILlON A.B., GIRLING R.D., GRIFFIN C.T., 2013 - Organic soils promote the efficacy of entomopathogenic nematodes, with different foraging strategies, in the control of a major forest pest: A metaanalysis of field trial data. - Biological Control, 65: 357-364.

Williams C.D., Dillon A.B., HaRvey C.D., HeNnessy R., MC NAMARA L., GRIFFIN C.T., 2013 - Control of major pest of forestry, Hylobius abietes, with entomopathogenic nematodes and fungi using eradicant and prophylactic strategies. - Forest Ecology and Management, 305: 212-222. 